\title{
Animal-Type Melanoma - a Mini-Review Concerning One of the Rarest Variants of Human Melanoma
}

\author{
Melanom animálního typu - velmi vzácná varianta lidského \\ melanomu
}

\author{
Roncati L. ${ }^{1}$, Piscioli F. ${ }^{2}$ \\ ' Department of Medical and Surgical Sciences, Institute of Pathology, University Hospital of Modena, Italy \\ 2 Provincial Health Care Services, Institute of Pathology, Santa Maria del Carmine Hospital, Rovereto, Italy
}

Described for centuries in the equines, especially gray horses, as "equine melanotic disease", it was later recognized in non-equine animal models and in humans, particularly on non UV-exposed skin. Animal-type melanoma, also known as pigmented epithelioid melanocytoma (PEM), is characterized by nodules and fascicles of epithelioid transformed melanocytes with pleomorphic nuclei and striking pigmentation, dendritic cells, numerous melanophages and, sometimes, lymphocytic infiltrate $[1,2]$. Up-to-date, only small series have been reported in humans and, therefore, its biological behavior remains unclear [3]. In 2010, Ludgate et al. examined the clinical behavior of 8 cases of equivocal and 14 cases of unequivocal PEM, concluding that it shows a propensity for regional nodal metastases [4]. By systematic review and meta-analysis of the English literature, in 2015, Vyas et al. have identified 190 cases of PEM. The median Breslow depth was $3.8 \mathrm{~mm}$, loco-regional recurrence was found in 15 cases, recurrence with distant metastases in 6 cases and death occurred in 5 patients [5]. Recently, Bax et al. have suggested that the tumor follows an indolent clinical course, with very low risk of spread beyond regional lymph nodes [6]. Given the complexity of the matter, Elder and Murphy proposed a histological categorization of PEM and PEM-like lesions, with distinctive clinicopathological and biologic attitudes [7]. In this review, we briefly highlight the current information about this rare disease.

\section{Epithelioid blue nevus resembling PEM}

It is a hyperpigmented, poorly circumscribed, dermal lesion, which shows heavily pigmented globular melanocytes, intermingled with hypopigmented spindle melanocytes. Commonly misinterpreted as classical blue nevus, in which markedly pigmented, bipolar, spindled cells are associated with a host-derived fibroblastic reaction, or as cellular blue nevus, a dermal-hypodermic benign neoplasm characterized by an alveolar or fascicular pattern of growth sometimes with neuronevoid aspects, or as PEM (see later); its exact identification is important because it is strongly associated with the Carney complex [8]. Conservative excision is generally recommended; moreover affected patients (and their relatives) should be considered at risk for other diseases of the Carney complex, especially cardiac myxoma [8].

\section{PEM}

Not associated with the Carney complex, it is quite similar to epithelioid blue nevus at scanning magnification,

\author{
The authors declare they have no potential \\ conflicts of interest concerning drugs, products, \\ or services used in the study. \\ Autoři deklarují, že $v$ souvislosti s předmětem \\ studie nemají žádné komerční zájmy. \\ The Editorial Board declares that the manuscript \\ met the ICMJE recommendation for biomedical \\ papers. \\ Redakční rada potvrzuje, že rukopis práce \\ splnil ICMJE kritéria pro publikace zasílané do \\ biomedicínských časopisů.

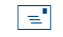 \\ Dr. Luca Roncati, MD, PhD \\ Department of Medical and Surgical \\ Sciences \\ Institute of Pathology \\ University Hospital of Modena \\ Policlinico \\ via del Pozzo, 71 \\ I-41124 Modena, Italy \\ e-mail:emailmedical@gmail.com \\ Submitted/Obdrženo: 17. 6. 2017 \\ Accepted/Prijato: 1.11.2018
}

doi: 10.14735/amko2018463

but cytological atypia and sparse low mitogenicity are encountered by a careful histological inspection, exactly as observable in melanocytic tumors of uncertain malignant potential (MELTUMP) [9-11]. When epidermal pagetoid diffusion and overtly anaplastic nuclei are present, a diagnosis of 
malignant melanoma with prominent pigment synthesis can be also proposed [2]. Although the tumor can be lethal given the depth of invasion according to Magro et al., it seems to be less aggressive than other usual or unusual vertical growth phase melanomas [1,2]. Local lymph nodes are often involved by metastases - lymph node sentinel biopsy is recommended and a wide re-excision (1-2cm margins) must be performed. Follow-up, as in any case of invasive malignant melanoma, should be conducted [2].

\section{Tumoral melanosis mimicking PEM}

It is a nodular cluster of melanophages, and it may represent a complete regression of a vertical growth phase melanoma or of a pigmented basal cell carcinoma [7]. In the radial and vertical growth phases, regression has negative impact on prognosis [12-16]; therefore, the follow-up should be very accurate since the lesion could be the result of a preceding, completely regressed melanoma [17-21].

A proper diagnostic framing is crucial in these controversial cases and a good histology in the hands of an expert dermatopathologist remains the most reliable diagnostic starting point. Moreover, a loss of expression of CAMPdependent protein kinase type I-alpha regulatory subunit, an enzyme encoded by the tumor-suppressor gene PRKAR1A, has been found in PEM, but not in common melanoma or other melanocytic lesions [22]. Therefore, it appears to have a great diagnostic value in helping to distinguish PEM from PEM-like lesions, which mimic the former histologically.

\section{References}

1. Zembowicz A, Carney JA, Mihm MC. Pigmented epithelioid melanocytoma: a low-grade melanocytic tumor with metastatic potential indistinguishable from animal-type melanoma and epithelioid blue nevus. Am J Surg Pathol 2004; 28(1): 31-40

2. Magro CM, Crowson AN, Mihm MC. Unusual variants of malignant melanoma. Mod Pathol 2006; 19(Suppl 2): 41-70. doi: 10.1038/modpathol.3800516.

3. Mandal RV, Murali R, Lundquist KF et al. Pigmented epithelioid melanocytoma: favorable outcome after 5-year follow-up. Am J Surg Pathol 2009; 33(12): 1778-1782. doi: 10.1097/PAS.0b013e3181b94f3c.

4. Ludgate MW, Fullen DR, Lee J et al. Animal-type melanoma: a clinical and histopathological study of 22 cases from a single institution. Br J Dermatol 2010; 162(1): 129-136. doi: 10.1111/j.1365-2133.2009.09271x

5. Vyas R, Keller JJ, Honda K et al. A systematic review and meta-analysis of animal-type melanoma. J Am Acad Dermatol 2015; 73(6): 1031-1039. doi: 10.1016/J. jaad.2015.08.016

6. Bax MJ, Brown MD, Rothberg PG et al. Pigmented epithelioid melanocytoma (animal type melanoma): an institutional experience. J Am Acad Dermatol 2017; 77(2): 328-332. doi: 10.1016/j.jaad.2017.01.029.

7. Elder DE, Murphy GF. Melanocytic tumors of the skin AFIP atlas of tumor pathology. 4th ed. Washington, DC American Registry of Pathology 2010

8. Carney JA, Ferreiro JA. The epithelioid blue nevus. A multicentric familial tumor with important associations, including cardiac myxoma and psammomatous melanotic schwannoma. Am J Surg Pathol 1996; 20(3): 259-272. 9. Piscioli F, Pusiol T, Roncati L. Diagnostic approach to melanocytic lesion of unknown malignant potential. Melanoma Res 2016; 26(1): 91-92. doi: 10.1097/ CMR.0000000000000215.
10. Roncati L, Piscioli F, Pusiol T. SAMPUS, MELTUMP and THIMUMP - diagnostic categories characterized by uncertain biological behavior. Klin Onkol 2017: 30(3): 221-223. doi: 10.14735/amko2017221.

11. Piscioli F, Pusiol T, Roncati L. Diagnostic disputes regarding atypical melanocytic lesions can be solved by using the term MELTUMP. Turk Patoloji Derg 2016; 32(1): 63-64. doi: 10.5146/tjpath.2015.01330.

12. Roncati L, Piscioli F, Pusiol T. The significance of regression in thin melanoma of the skin. Ir J Med Sci 2018; 187(1): 95-96. doi: 10.1007/s11845-017-1612-1.

13. Roncati $L$, Piscioli F, Pusiol T. Sentinel lymph node in thin and thick melanoma. Klin Onkol 2016; 29(5): 393-394. 14. Roncati L, Piscioli F, Pusiol T. Current controversies on sentinel node biopsy in thin and thick cutaneous melanoma. Eur J Surg Oncol 2017; 43(2): 506-507. doi: 10.1016/j.ejso.2016.09.014.

15. Piscioli F, Pusiol T, Roncati L. Wisely choosing thin melanomas for sentinel lymph node biopsy. J Am Acad Dermatol 2017; 76(1): e25. doi: 10.1016/j.jaad.2016.08.069.

16. Piscioli F, Pusiol T, Roncati L. Higher predictive value of sentinel lymph node biopsy in patients with histological subcategorization of thin melanoma. Int J Dermatol 2017; 56(5): e93-e94. doi: 10.1111/ijd.13548.

17. Roncati L, Piscioli F, Pusiol T. Surgical outcomes reflect the histological types of cutaneous malignant melanoma. J Eur Acad Dermatol Venereol 2016; 31(6): e279-e280. doi: 10.1111/jdv.14023.

18. Piscioli F, Pusiol T, Roncati L. Critical points of T1 stage in primary melanoma. Melanoma Res 2017; 27(4): 399. doi: 10.1097/CMR.0000000000000357.

19. Piscioli F, Pusiol T, Roncati L. Nowadays a histological sub-typing of thin melanoma is demanded for a proper patient management. J Plast Reconstr Aesthet Surg 2016; 69(11): 1563-1564. doi: 10.1016/j.bjps.2016.08.026. 20. Roncati L, Pusiol T, Piscioli F. Thin melanoma: a generic term including four histological subtypes of cutaneous melanoma. Acta Dermatovenerol Croat 2016; 24(4): 169-174.

21. Piscioli F, Pusiol T, Roncati L. Thin melanoma subtyping fits well with the American Joint Committee on Cancer staging system. Melanoma Res 2016; 26(6): 636. doi: 10.1097/CMR.0000000000000301.

22. Zembowicz A, Knoepp SM, Bei T et al. Loss of expression of protein kinase a regulatory subunit 1alpha in pigmented epithelioid melanocytoma but not in melanoma or other melanocytic lesions. Am J Surg Pathol 2007; 31(11): 1764-1775. doi: 10.1097/PAS.0b013e318057faa7. 